Working Paper

Research Department

Federal Reserve Bank of Minneapolis 
Federal Reserve Bank of Minneapolis

Research Department

\title{
Capital Market Imperfections in a Monetary Growth Model
}

\author{
John H. Boyd and Bruce D. Smith*
}

Working Paper 533

July 1994

*Boyd, Federal Reserve Bank of Minneapolis and University of Minnesota; Smith, Federal Reserve Bank of Minneapolis and Cornell University. We would like to thank Randy Wright for his extremely helpful input on this paper and David Hammond for excellent research assistance. The views expressed herein are those of the authors and not necessarily those of the Federal Reserve Bank of Minneapolis or the Federal Reserve System. 


\section{Introduction}

Most monetary growth models share several common features. Under specifications of government policy that fix a rate of growth for the money supply, such models typically deliver unique monetary steady state equilibria. These monetary steady states are generally saddles, and dynamical equilibria approaching them do so monotonically. Moreover, as the government increases the rate of growth of the money supply (and the steady state rate of inflation) the steady state capital stock will not decline, and indeed will rise in models displaying a version of the Mundell-Tobin effect. ${ }^{1}$ Finally, such models generally lack any specific allocative function for banks or other credit market institutions, and they do not explicitly model any financial market frictions.

These features of money and growth models preclude any discussion of a variety of interesting issues. First, when such models deliver unique monetary steady states, similar economies (with money) must have similar steady state capital stocks, output levels, rates of return on savings, etc. In particular, development trap phenomenon, in which intrinsically similar economies have different long-run behavior, cannot occur when money has value. This is a very strong implication of such models.

Second, when monetary steady states are saddles, there is complete determinacy of monetary equilibrium. This fact precludes any consideration of the possibility that the presence of money and financial markets is a potential source of indeterminacies, as is stressed in a long descriptive literature on monetary economics. ${ }^{2}$ Moreover, the implication that dynamical equilibria display monotonic adjustment of the capital stock, output level, the rate of return on savings, and the inflation rate does not permit any analysis of the possibility that activity in money and financial markets is a potential source of endogenous volatility in production economies, even though it is widely believed that this should be the case. ${ }^{3}$ 
Third, the implication that the steady state capital stock (or capital-labor ratio) and output (or productivity) level are nonnegatively related to the steady state inflation rate is in direct contradiction to a large body of evidence on the long-run correlations between inflation and real activity across different countries. ${ }^{4}$

In this paper we consider a monetary growth model that is essentially identical to that of Diamond (1965) and Tirole (1985), except that it explicitly models credit markets, a credit market friction, and an allocative function for financial intermediaries. More specifically, we assume that some agents must borrow in order to finance capital investments, that this borrowing is subject to a costly state verification problem of the type originally considered by Townsend (1979), and that this state verification problem leads to credit rationing in the manner described by Gale and Hellwig (1985) and Williamson (1986, 1987). In addition, as noted by Williamson (1986), this kind of environment contains an explicit allocative function for intermediation.

In the absence of those aspects of the model related to credit market frictions, this economy displays all of the standard features of monetary growth models that we have noted above. In the presence of the credit market friction, however, matters are substantially different. First, if any monetary steady state equilibria exist, there will generically be two of them. One of these will have a low capital stock and output level, and will be a saddle. Dynamical equilibria approaching this steady state display monotonic time paths of all endogenous variables. The other steady state will have a relatively high capital stock and output level, and this steady state will be a sink if the rate of money growth is not "too high". Thus monetary equilibria can be indeterminate, as conjectured by Mints (1945), Friedman (1960), and a variety of others. Finally, monetary equilibria can display either damped oscillation as steady state equilibria are approached, or can display limit cycles in which oscillation does not dampen over time. Thus financial market frictions are a potential source of both indeterminacy and enhanced economic volatility. 
Second, the low-capital-stock steady state exhibits a Mundell-Tobin effect: higher rates of money growth increase the steady state capital stock and output level. However, this effect is reversed in the high-capital-stock steady state, where higher rates of money growth decrease the level of real activity.

Third, the analysis permits us to address two issues that arise in the literature on financial markets and economic development. ${ }^{5}$ The development literature stresses a sense in which the existence of relatively efficient financial markets is observed in economies with high levels of real activity; and similarly, economies with inefficient financial markets have low levels of real activity. In the model presented here, there may be two monetary steady states, one of which is a sink and one of which is a saddle. Two intrinsically similar (or even identical) economies, with similar (or even identical) initial capital stocks, can therefore display very different long-run behavior. In particular, a given economy can either follow the saddle path to the low-capital-stock steady state, or follow any of the continuum of paths approaching the high-capital-stock steady state. Thus development trap phenomena are ubiquitous. Moreover, despite the fact that there are no intrinsic differences between their financial systems, economies that approach the high capital stock steady state have more efficient financial markets-in a sense to be described presently - than do economies that approach the low-capital-stock steady state.

In addition, literature in the McKinnon-Shaw tradition often argues that rates of return on savings are positively related to the level of the capital stock. This cannot occur, of course, in any strictly concave growth model where the rate of return on savings is an increasing function of the marginal product of capital. This result is observed in our economy around the high-capital-stock steady state, however, and is directly related to the reversal of the Mundell-Tobin effect.

Before proceeding to a formal analysis, we briefly sketch the intuition underlying these results. We consider a two-period lived overlapping generations model in which all agents work 
when young and are retired when old. A single final good is produced using capital and labor as inputs. In addition some agents ("borrowers") have access to a stochastic technology for converting current consumption into future capital, while other agents ("lenders") do not. The capital investment technology yields a random return which is observed by the initiating investor, but which can be observed by other agents only by incurring a fixed cost.

As is standard in the literature on costly state verification, we assume that investment projects are indivisible. Borrowers combine their own young period income-which is simply their young period wage rate-along with credit obtained externally in order to finance these projects. As noted previously by Bernanke and Gertler (1989), the greater the amount of internal financing of projects (here just the real wage rate), the less severe is the costly state verification problem. It is this feature that permits multiple steady state equilibria to be observed.

In a monetary steady state, the real rate of return to lenders must be equated to the rate of return on real balances, which in steady state is fixed by the (exogenously given) rate of money growth. There are two ways that this can occur. In an equilibrium with a low capital stock-and a correspondingly low real wage rate-the marginal product of capital is high, which tends to make the return on loans to investors high. However, there is also relatively little internal financing of investment projects. This exacerbates the costly state verification problem, which tends to reduce the return on loans. On the other hand, the high-capital-stock steady state displays a low marginal product of capital, but a high level of internal finance. Both situations are consistent with the same real return to lenders, permitting the existence of multiple steady states.

In the high-capital-stock steady state there is a relatively large amount of internal financing of investment projects. As a consequence, the costly state verification problem is correspondingly less severe, and financial markets function with relative efficiency. On the other hand, in the lowcapital-stock steady state there is relatively little internal financing of investments, the costly state 
verification problem is magnified, and financial markets operate with comparative inefficiency. Thus economies with well-functioning financial markets will have high levels of real activity, and conversely.

It should be noted that this kind of phenomenon occurs in a variety of contexts. Thus we view one of the contributions of this paper to be an illustration that the following point is a fairly general one: when the severity of financial market frictions is endogenous, there is considerable scope for the proliferation of equilibria, steady state or otherwise. In addition, when endogenous factors influence the significance of credit market imperfections, there is considerable scope for indeterminacy and enhanced volatility. Further illustrations of this observation appear in Schreft and Smith $(1994 a, b)$, where financial market frictions are present in the form of spatial separation and limited communication. They find that there are often multiple monetary steady states, with one being a saddle and the other (potentially) being a sink. Dynamical equilibrium paths approaching the latter steady state can display damped oscillation and, parenthetically, one of the steady states will have a capital stock that is inversely related to the rate of inflation.

Another illustration of these points appears in Boyd and Smith (1993c), which considers a two-country, nonmonetary version of the model of this paper. As they illustrate, the presence of a credit market friction leads to the existence of multiple steady state equilibria where two intrinsically identical economies have different steady state capital stocks and income levels. In addition, the same friction can lead to economic fluctuations that are impossible in its absence, or in the closed economy version of the same model without money. Thus, in short, the presence of credit market frictions in otherwise familiar growth models will result in substantially different kinds of equilibrium behavior being observed.

The remainder of the paper proceeds as follows. Section I describes the model economy, while Section II lays out the nature of trade in credit and factor markets. Section III analyzes a 
general equilibrium with credit rationing but in the absence of money. Section IV reintroduces money, and analyzes both steady state and dynamical equilibria. Section $\mathrm{V}$ discusses the potential for development trap phenomena, while Section VI concludes.

\section{The Model}

The economy we examine consists of an infinite sequence of two-period lived, overlapping generations. Each generation is identical in size and composition, and contains a continuum of agents with unit mass. Within each generation agents are divided into two types: "potential borrowers" and "lenders". A fraction $\alpha \in(0,1)$ of the population is potential borrowers. Throughout we let $t=0,1, \ldots$ index time.

At each date a single final good is produced using a constant returns to scale technology with capital and labor as inputs. Let $\mathrm{K}_{\mathrm{t}}$ denote the time $\mathrm{t}$ capital input, and $\mathrm{L}_{\mathrm{t}}$ denote the time $\mathrm{t}$ labor input of a representative firm. Then final output is $F\left(K_{t}, L_{b}\right)$. We assume that $F$ is increasing in each argument, strictly concave, and that $\mathrm{F}(0, \mathrm{~L})=\mathrm{F}(\mathrm{K}, 0)=0$, for all $\mathrm{K}, \mathrm{L}$. In addition, if $\mathrm{k} \equiv \mathrm{K} / \mathrm{L}$ and if $f(k)$ denotes the intensive production function ${ }^{6}$, then we assume that $f$ satisfies the standard Inada conditions. Finally, we assume that the inherited capital stock at date $\mathrm{t}$ is used in production, and that thereafter it depreciates completely.

We assume that all young agents are endowed with one unit of labor, which is supplied inelastically, and that agents supply no labor when old. Agents other than the old of period zero have no endowment of capital or final goods, while the initial old agents have an aggregate capital endowment of $\mathrm{K}_{0}>0$.

Agents of all types are assumed to care only about old age consumption and, in addition, all agents are risk neutral. Thus all young period income is saved. 
Potential borrowers and lenders are differentiated by the fact that each potential borrower has access to a stochastic linear technology for converting date $t$ final goods into date $t+1$ capital. Lenders have no access to this technology.

The capital investment technology has the following properties. First, the investment technology is indivisible: each potential borrower has one investment project which can only be operated at the scale $\mathrm{q}$. In particular, $\mathrm{q}>0$ units of the final good invested in one project at $\mathrm{t}$ yields zq units of capital at $\mathrm{t}+1$, where $\mathrm{z}$ is an iid (across agents) random variable that is realized at the beginning of $t+1$. We let $G$ denote the probability distribution of $z$, and assume that $G$ has a differentiable density function $g$ with support $[0, \bar{z}]$. Let

$$
\hat{z} \equiv \int_{0}^{\bar{z}} z g(z) d z
$$

be the expected value of $z$.

The amount of capital produced by any investment project can be observed costlessly only by the project owner. Any agent other than the project owner can observe the return on the project only by bearing a fixed cost of $\gamma>0$ units of capital. ${ }^{7}$

\section{Trade}

\section{A. Factor Markets}

We assume that capital and labor are traded in competitive factor markets at each date. Thus if $w_{t}$ denotes the time $t$ real wage rate and $\rho_{t}$ is the time $t$ rental rate of capital, the standard factor pricing relationships obtain:
(1) $\quad \rho_{\mathrm{t}}=\mathrm{f}^{\prime}\left(\mathrm{k}_{\mathrm{t}}\right)$
(2) $\quad \mathrm{w}_{\mathrm{t}}=\mathrm{f}\left(\mathrm{k}_{\mathrm{t}}\right)-\mathrm{k}_{\mathrm{t}} \mathrm{f}^{\prime}\left(\mathrm{k}_{\mathrm{t}}\right) \equiv \mathrm{w}\left(\mathrm{k}_{\mathrm{t}}\right)$. 
Notice that $\mathrm{w}^{\prime}(\mathrm{k})>0$ holds and, in addition, we assume throughout that

(a.1) $\quad w^{\prime \prime}(k)<0 ; \quad k \geq 0$.

(a.1) is satisfied if, for instance, $f$ is any CES production function with elasticity of substitution no less than one. The assumption (a.1) guarantees the uniqueness of a nontrivial steady state equilibrium in the model without money.

\section{B. Credit Markets}

All young agents at $t$ supply one unit of labor inelastically, earning the real wage rate $\mathrm{w}_{\mathrm{t}}$. For lenders this income is saved, either in the form of money or in the form of loans to borrowers. We can think of all the latter credit extension as being intermediated in the manner described by Williamson (1986).

Potential borrowers also have the young period income $\mathrm{w}_{t}$, and if

\section{(a.2) $\quad \mathrm{q}>\mathrm{w}\left(\mathrm{k}_{\mathrm{t}}\right)$}

for all "relevant" values of $k_{t}$-as we assume-then borrowers must obtain external financing to operate their investment projects. Let $b_{t}$ denote borrowing by the operator of a funded project (in real terms) at $\mathrm{t}$; clearly

$$
b_{t}=q-w\left(k_{t}\right)
$$

If potential borrowers wish to obtain external funding-which is necessary to operate their projects-they do so by announcing loan contract terms. These announced contract terms are either accepted or rejected by intermediaries: borrowers whose terms are accepted then operate their projects. Following Williamson $(1986,1987)$, a loan contract consists of the following objects. First, there is a set of project return realizations $A_{t}$ for which verification of the project return occurs at $t$. Verification of the state of the project does not occur if $z \in B_{t} \equiv[0, \bar{z}]-A_{t}{ }^{8}$ Second, if 
$\mathrm{z} \in \mathrm{A}_{\mathrm{t}}$, then the contractual repayment on the loan can meaningfully be made contingent on the project return. Thus if $z \in A_{t}$ we denote the promised payment (per unit borrowed) by $R_{t}(z)$. On the other hand, if $\mathrm{z} \in \mathrm{B}_{\mathrm{t}}$ then the loan payment cannot meaningfully depend on the project return, and the only incentive compatible loan contract offers an uncontingent payment of $x_{t}$ (per unit borrowed) for all $\mathrm{z} \in \mathrm{B}_{\mathrm{t}}$. All payments specified by any loan contract are in real terms.

Loan contracts offered by borrowers are either accepted or rejected by intermediaries who-without loss of generality-we can think of as making all loans. Thus intermediaries take deposits, make loans, and conduct monitoring of project returns as required by the contracts they accept. We assume that any lender can establish an intermediary. Then, in equilibrium, intermediaries will earn zero profits and have a nonstochastic return on their portfolios. Thus intermediaries need not be monitored by their depositors. ${ }^{9}$

Intermediaries accept deposits taking the gross return that must be paid on them $-r_{t+1}$ between $t$ and $t+1$-as given, and they act as if they can obtain any desired quantity of deposits at that rate. It follows that intermediaries will accept any loan contract offers yielding an expected return of at least $r_{t+1}$. Thus loan contract offers (that have any prospect of acceptance) must satisfy the expected return constraint

$$
\int_{A_{t}}\left[R_{t}(z) b_{t}-\rho_{t+1} \gamma\right] g(z) d z+x_{t} b_{t} \int_{B_{t}} g(z) d z \geq r_{t+1} b_{t}
$$

In particular, expected repayments

$$
\int_{A_{t}} R_{t}(z) b_{t} g(z) d z+b_{t} x_{t} \int_{B_{t}} g(z) d z
$$

must at least cover the intermediary's cost of funds $-r_{t+1} b_{t}-$ plus the real expected monitoring cost

$$
\rho_{\mathrm{t}+1} \gamma \int_{\mathrm{A}_{\mathrm{t}}} \mathrm{g}(\mathrm{z}) \mathrm{dz}
$$


The expected monitoring cost depends on $\rho_{\mathrm{t}+1}$, of course, because $\gamma$ units of capital are expended when project returns are verified. Finally, since only project owners directly observe project returns, they must have the proper incentives to correctly reveal when a monitoring state has occurred. The appropriate incentive constraint is

$$
\mathrm{R}_{\mathrm{t}}(\mathrm{z}) \leq \mathrm{x}_{\mathrm{t}} ; \quad \mathrm{z} \in \mathrm{A}_{\mathrm{t}}
$$

Borrowers, then, will maximize their own expected utility by choice of contract terms, subject to the constraints just described. Therefore announced loan contracts at date $t$ will be selected to maximize

$$
q \hat{z} \rho_{t+1}-b_{t} \int_{A_{t}} R_{t}(z) g(z) d z-b_{t} x_{t} \int_{B_{t}} g(z) d z
$$

subject to (4), (5), and the appropriate nonnegativity constraints; that is

$$
\begin{aligned}
& \mathrm{R}_{\mathrm{t}}(\mathrm{z}) \leq \mathrm{zq} \rho_{\mathrm{t}+1} / \mathrm{b}_{\mathrm{t}} ; \quad \mathrm{z} \in \mathrm{A}_{\mathrm{t}} \\
& \mathrm{x}_{\mathrm{t}} \leq \inf _{\mathrm{z} \in \mathrm{B}_{\mathrm{t}}}\left[\mathrm{zq} \rho_{\mathrm{t}+1} / \mathrm{b}_{\mathrm{t}}\right] .
\end{aligned}
$$

Equations (6) and (7) require that the borrower can never repay more than the real value of the capital yielded by his project, which in state $\mathrm{z}$ is $\mathrm{qz} \rho_{\mathrm{t}+1}$ at $\mathrm{t}+1$.

The solution to the borrower's problem is, as is well-known, to offer a standard debt contract (modified for the presence of internal finance). In particular, the borrower either repays $x_{t}$ (principal plus interest) or else defaults. In the latter case the lender monitors the project, and retains the net of monitoring cost proceeds of the project. Formally,

Proposition 1. Suppose $q>b_{t}$. Then the optimal contractual loan terms satisfy

(8) $\quad \mathrm{R}_{\mathrm{t}}(\mathrm{z})=\mathrm{zq} \rho_{\mathrm{t}+1} / \mathrm{b}_{\mathrm{t}} ; \quad \mathrm{z} \in \mathrm{A}_{\mathrm{t}}$

(9) $A_{t}=\left[0, x_{t} b_{t} / q \rho_{t+1}\right)$ 


$$
\int_{A_{t}}\left[R_{t}(z)-\left(\gamma \rho_{t+1} / b_{t}\right)\right] g(z) d z+x_{t} \int_{B_{t}} g(z) d z=r_{t+1}
$$

The proof of Proposition 1 is standard ${ }^{10}$, and we omit it here.

For future reference, suppose we substitute (8) and (9) into (10). We then obtain

$$
\begin{aligned}
& \int_{A_{t}}\left[R_{t}(z)\right.\left.-\left(\rho_{t}+1 / b_{t}\right)\right] g(z) d z+x_{t} \int_{B_{t}} g(z) d z \\
&= x_{t}\left\{1-G\left(x_{t} b_{t} / q \rho_{t+1}\right)\right\}-\left(\gamma \rho_{t+1} / b_{t}\right) G\left(x_{t} b_{t} / q \rho_{t+1}\right)+\int_{0}^{\left(x_{t} b_{t} / q \rho_{t+1}\right)}\left(q \rho_{t+1} / b_{t}\right) z g(z) d z \\
&= x_{t}-\left(\gamma \rho_{t+1} / b_{t}\right) G\left(x_{t} b_{t} / q \rho_{t+1}\right)-\left(q \rho_{t+1} / b_{t}\right) \int_{0}^{\left(x_{t} b_{t} / q \rho_{t+1}\right)} \mathrm{G}(\mathrm{z}) \mathrm{dz} \\
& \equiv \pi\left[x_{t} ;\left(b_{t} / \rho_{t+1}\right)\right]=r_{t+1}
\end{aligned}
$$

where the second equality follows from integration by parts. Thus the function $\pi$ gives the expected return to the lender as a function of the gross loan rate, $x_{t}$, the amount of external finance on the project, $b_{t}$, and the future relative price of capital, $\rho_{t+1}$.

It will be useful in what follows to put some additional structure on the function $\pi$. In particular, we assume that

(a.3) $\mathrm{g}(\mathrm{z})+(\gamma / \mathrm{q}) \mathrm{g}^{\prime}(\mathrm{z}) \geq 0 ;$ for all $\mathrm{z} \in[0, \bar{z}]$.

(a.3) implies that $\pi_{11}<0$. Hence if

$$
\pi_{1}\left[0,\left(\mathrm{~b}_{\mathrm{t}} / \rho_{\mathrm{t}+1}\right)\right]>0
$$

the function $\pi$ has the configuration depicted in Figure 1. Evidently, there is a unique value of $x_{t}$ (depending on the value of $\left.b_{t} / \rho_{t+1}\right)$-which we denote by $\hat{x}\left(b_{t} / \rho_{t+1}\right)$-which maximizes the expected return that can be offered to any lender. $\hat{x}$ is clearly defined implicitly by 


$$
\pi_{1}\left[\hat{x}\left(\mathrm{~b}_{\mathfrak{t}} / \rho_{\mathrm{t}+1}\right) ; \mathrm{b}_{\mathrm{t}} / \rho_{\mathrm{t}+1}\right] \equiv 1-(\gamma / \mathrm{q}) \mathrm{g}\left[\hat{\mathrm{x}}\left(\mathrm{b}_{\mathrm{t}} / \rho_{\mathrm{t}+1}\right)\left(\mathrm{b}_{\mathfrak{t}} / \mathrm{q} \rho_{\mathrm{t}+1}\right)\right]-\mathrm{G}\left[\hat{\mathrm{x}}\left(\mathrm{b}_{\mathrm{t}} / \rho_{\mathrm{t}+1}\right)\left(\mathrm{b}_{\mathrm{t}} / \mathrm{q} \rho_{\mathrm{t}+1}\right)\right] \equiv 0 .
$$

Equation (12) and assumption (a.3) imply that

$$
\hat{\mathrm{x}}\left(\mathrm{b}_{\mathrm{t}} / \rho_{\mathrm{t}+1}\right)\left(\mathrm{b}_{\mathrm{t}} / \mathrm{q} \rho_{\mathrm{t}+1}\right) \equiv \eta
$$

where $\eta>0$ is a constant satisfying $1-(\gamma / \mathrm{q}) \mathrm{g}(\eta)-\mathrm{G}(\eta) \equiv 0$.

\section{Credit Rationing}

One feature of the environment under consideration-which was originally noted by Gale and Hellwig (1985) and Williamson $(1986,1987)$-is that it can allow the existence of unfulfilled demand for credit. In particular, if all borrowers desire to operate their projects at date $t$, the total (per capita) demand for credit is $\alpha \mathrm{q}$. The total per capita supply of saving is $w\left(k_{t}\right)$ at $t$. Thus if

(a.5) $\alpha q>w\left(k_{t}\right)$

holds for all $t \geq 0$, credit demand exceeds credit supply, and credit must be rationed. In order for credit rationing to exist, however, it must be the case that

$$
x_{t}=\hat{x}\left(b_{t} / q \rho_{t+1}\right)
$$

When (14) holds, all potential borrowers are offering the interest rate that maximizes a prospective lender's expected rate of return. Rationed (unfunded) potential borrowers cannot then obtain credit by changing loan contract terms, since doing so simply reduces the expected return perceived by (all) lenders. Thus if (a.5) and (14) hold at date t, credit rationing is an equilibrium outcome. We henceforth focus on economies where credit rationing occurs at all dates. ${ }^{11}$ 


\section{Payoffs Under Credit Rationing}

We now describe the expected payoffs received by lenders and (funded) borrowers at $t$ when credit is rationed. For lenders, equations (11) and (14) imply that the expected return on bank deposits (and loans) satisfies

$$
\begin{aligned}
\mathrm{r}_{\mathrm{t}+1} & =\pi\left[\hat{\mathbf{x}}\left(\mathrm{b}_{\mathrm{t}} / \rho_{\mathrm{t}+1}\right) ; \mathrm{b}_{\mathrm{t}} / \rho_{\mathrm{t}+1}\right] \\
& \equiv \mathrm{q}\left(\rho_{\mathrm{t}+1} / \mathrm{b}_{\mathrm{t}}\right)\left\{\hat{\mathbf{x}}\left(\mathrm{b}_{\mathrm{t}} / \rho_{\mathrm{t}+1}\right)\left(\mathrm{b}_{\mathrm{t}} / \mathrm{q} \rho_{\mathrm{t}+1}\right)-(\gamma / \mathrm{q}) \mathrm{G}\left[\hat{\mathrm{x}}\left(\mathrm{b}_{\mathfrak{t}} / \rho_{\mathrm{t}+1}\right)\left(\mathrm{b}_{\mathrm{t}} / \mathrm{q} \rho_{\mathrm{t}+1}\right)\right]-\int_{0}^{\hat{\mathrm{x}} \mathrm{b}_{\mathrm{t}} / \mathrm{q} \rho_{\mathrm{t}+1}} \mathrm{G}(\mathrm{z}) \mathrm{dz}\right\} \\
& \equiv \mathrm{q}\left(\rho_{\mathrm{t}+1} / \mathrm{b}_{\mathrm{t}}\right)\left[\eta-(\gamma / \mathrm{q}) \mathrm{G}(\eta)-\int_{0}^{\eta} \mathrm{G}(\mathrm{z}) \mathrm{dz}\right] .
\end{aligned}
$$

In particular, the return on savings between $t$ and $t+1$ depends only on the ratio $\rho_{t+1} / b_{t}$ and parameters (and is proportional to that ratio) when credit rationing obtains.

It is also straightforward to demonstrate that the expected utility of a funded borrower under credit rationing is given by

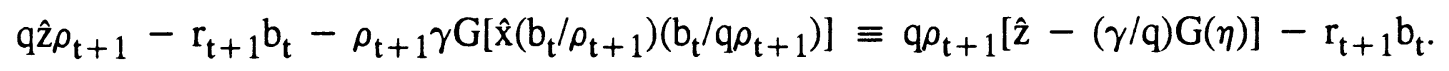

Since any potential borrower always has the option of foregoing his project and depositing his income in a bank, all potential borrowers can guarantee themselves the utility level $r_{t+1} w_{t}$. Thus (potential) borrowers prefer borrowing to lending under credit rationing iff

$$
q \rho_{t+1}[\hat{z}-(\gamma / q) G(\eta)]-r_{t+1} b_{t} \geq r_{t+1} w_{t}
$$

We now define 


$$
\begin{aligned}
& \phi \equiv \hat{\mathrm{z}}-(\gamma / \mathrm{q}) \mathrm{G}(\eta)^{12} \\
& \psi \equiv \mathrm{q}\left[\eta-(\gamma / \mathrm{q}) \mathrm{G}(\eta)-\int_{0}^{\eta} \mathrm{G}(\mathrm{z}) \mathrm{dz}\right] .
\end{aligned}
$$

Then, by (15),

$$
\mathrm{r}_{\mathrm{t}+1}=\psi\left(\rho_{\mathrm{t}+1} / \mathrm{b}_{\mathrm{t}}\right) \equiv \psi\left\{\rho_{\mathrm{t}+1} /\left[\mathrm{q}-\mathrm{w}\left(\mathrm{k}_{\mathrm{t}}\right)\right]\right\}
$$

Moreover, using (3) in (16) yields

$$
\phi \mathrm{q} \rho_{\mathrm{t}+1} \geq \mathrm{r}_{\mathrm{t}+1} \mathrm{q}
$$

Then (17) and (18) imply that

$$
\phi\left[q-w\left(k_{t}\right)\right] \geq \psi
$$

must hold for all $t \geq 0$ in order for borrowers to wish to operate their projects. Of course in view of (a.5), a sufficient condition for (19) to hold is that

$$
(1-\alpha) \phi \mathrm{q} \geq \psi
$$

\section{Money}

We assume that the initial old at time zero are endowed with an initial per capita money stock of $M_{-1} \geq 0$. Thereafter, the government allows the money supply to grow at the constant (gross) rate $\sigma \geq 1$, which it selects once and for all. Thus

$$
\mathrm{M}_{\mathrm{t}+1}=\sigma \mathrm{M}_{\mathrm{t}} ; \quad \mathrm{t} \geq-1
$$

For simplicity we assume that the government simply uses the implied seigniorage revenue in order to fund the endogenous sequence of per capita expenditures $\left\{g_{t}\right\}$. Thus, if $p_{t}$ is the time t price level, the government budget constraint implies that 


$$
g_{t}=\left(M_{t}-M_{t-1}\right) / p_{t} ; \quad t \geq 0
$$

Letting $\mathrm{m}_{\mathrm{t}} \equiv \mathrm{M}_{\mathrm{t}} / \mathrm{p}_{\mathrm{t}}$ denote per capita real balances, (21) and (22) imply that

$$
\mathrm{g}_{\mathrm{t}}=[(\sigma-1) / \sigma] \mathrm{m}_{\mathrm{t}} ; \quad \mathrm{t} \geq 0
$$

Finally, in order for money and bank deposits to both be held, it is necessary that the gross return on bank deposits equal the gross return on real balances at each date. Thus

$$
p_{t} / p_{t+1}=r_{t+1} ; \quad t \geq 0
$$

\section{General Equilibrium: The Nonmonetary Case}

For future reference, it will be useful to examine a general equilibrium when $m_{t} \equiv 0$. We now consider this case, and take up the situation when $m_{t}>0$ in subsequent sections.

Let $\mu_{\mathrm{t}}$ denote the fraction of potential borrowers who do obtain credit at $\mathrm{t}$. Then total (per capita) loans are $\alpha \mu_{t}\left(q-w_{t}\right)$. The total supply of savings is $(1-\alpha) w_{t}$ plus $\alpha\left(1-\mu_{t}\right) w_{t}$, since unfunded borrowers simply deposit their income with an intermediary and, in effect, become lenders. Thus an equality between "sources" and "uses" of funds requires that

$$
\alpha \mu_{\mathrm{t}}\left[\mathrm{q}-\mathrm{w}\left(\mathrm{k}_{\mathrm{t}}\right)\right]=(1-\alpha) \mathrm{w}\left(\mathrm{k}_{\mathrm{t}}\right)+\alpha\left(1-\mu_{\mathrm{t}}\right) \mathrm{w}\left(\mathrm{k}_{\mathrm{t}}\right)
$$

since each funded borrower borrows $b_{t}=q-w\left(k_{t}\right)$. Equation (25) reduces to

$$
\alpha q \mu_{t}=w\left(k_{t}\right)
$$

Assumption (a.5) implies that $\mu_{\mathrm{t}}<1$ holds, for all $\mathrm{t} \geq 0$.

Under our assumption that returns on investment projects are iid across borrowers, the fact that there is a large number of borrowers implies that there is no aggregate randomness in this economy. In particular, the time $t+1$ per capita capital stock is simply $\hat{z} \alpha q \mu_{t}=\hat{z} w\left(k_{t}\right)$, less 
capital expended on monitoring at $t+1$. The amount of capital consumed by monitoring is simply $\gamma \alpha \mu_{\mathrm{t}} \mathrm{G}\left(\mathrm{x}_{\mathrm{t}} \mathrm{b}_{\mathrm{t}} / \mathrm{q} \rho_{\mathrm{t}+1}\right)=\gamma \alpha \mu_{\mathrm{t}} \mathrm{G}(\eta)=(\gamma / \mathrm{q}) \mathrm{G}(\eta) \mathrm{w}\left(\mathrm{k}_{\mathrm{t}}\right)$ under credit rationing. Thus

$$
\mathrm{k}_{\mathrm{t}+1}=[\hat{\mathrm{z}}-(\gamma / \mathrm{q}) \mathrm{G}(\eta)] \mathrm{w}\left(\mathrm{k}_{\mathrm{t}}\right)=\phi \mathrm{w}\left(\mathrm{k}_{\mathrm{t}}\right)
$$

gives the equilibrium law of motion for $k_{t}$ when credit is rationed at all dates.

If we assume that

$$
\text { (a.6) } \phi \mathrm{w}^{\prime}(0)>1
$$

then equation (26) has the configuration depicted in Figure 2. More specifically, equation (26) gives $\mathrm{k}_{\mathrm{t}+1}$ as an increasing, concave (by (a.1)) function of $\mathrm{k}_{\mathrm{t}}$. (a.6) implies that the locus defined by (26) lies above the $45^{\circ}$ line in Figure 2 for sufficiently small values of $k_{t}$, and standard arguments establish that it lies below the $45^{\circ}$ line for large enough values of $k_{t}$. Thus (a.2) and (a.6) imply the existence of a unique value $\mathrm{k}^{*}>0$ that satisfies $\mathrm{k}^{*}=\phi \mathrm{w}\left(\mathrm{k}^{*}\right)$.

In order for credit rationing to obtain in the steady state, is necessary that $\mathrm{k}^{*}$ satisfy two conditions. First

$$
\alpha \mathrm{q}>\mathrm{w}\left(\mathrm{k}^{*}\right)
$$

must hold (so that (a.5) is satisfied). Second

$$
\phi\left[q-w\left(k^{*}\right)\right] \geq \psi
$$

must hold (so that (19) is satisfied). If (27), (28), and $k_{0} \leq k^{*}$ hold, then our economy does experience credit rationing at all dates. It is straightforward to produce examples where (27), (28), and our other assumptions are satisfied. For instance, here is one such example.

Example 1. Let $\mathrm{f}(\mathrm{k})=\mathrm{Ak}^{\beta}$, with $\mathrm{A}=1$ and $\beta=0.5$. In addition, let $\mathrm{g}(\mathrm{z})=1 / \overline{\mathrm{z}}$, with $\overline{\mathrm{z}}=2$, and let $\gamma=3 \mathrm{q} / 2$. Then (27) and (28) are satisfied if $\mathrm{q}>0.174$ and $\alpha>0.625$. 


\section{General Equilibrium: The Monetary Case}

We now consider the situation when real balances are (potentially) positive. In this case, of course, equations (24) and (17) require that

$$
\mathrm{p}_{\mathrm{t}} / \mathrm{p}_{\mathrm{t}+1}=\mathrm{r}_{\mathrm{t}+1}=\psi \mathrm{f}^{\prime}\left(\mathrm{k}_{\mathrm{t}+1}\right) /\left[\mathrm{q}-\mathrm{w}\left(\mathrm{k}_{\mathrm{t}}\right)\right]
$$

In addition, "sources" and "uses" of funds must be equal. If $\mu_{\mathrm{t}}$ is the fraction of borrowers who are funded, then the "uses" of funds in real terms at $\mathrm{t}$ is $\alpha \mu_{\mathrm{t}} \mathrm{q}$ plus real balances; that is $\alpha \mu_{\mathrm{t}} \mathrm{q}+\mathrm{m}_{\mathrm{t}}$. "Sources" of funds are simply per capita savings; that is $\mathrm{w}\left(\mathrm{k}_{\mathrm{t}}\right)$. Thus

$$
\alpha \mu_{\mathrm{t}} \mathrm{q}=\mathrm{w}\left(\mathrm{k}_{\mathrm{t}}\right)-\mathrm{m}_{\mathrm{t}}
$$

must hold. ${ }^{13}$

We now note that the time $t+1$ per capita capital stock is simply $\hat{z} \alpha \mu_{t} q$, less capital expended on monitoring. As before, the latter quantity is $\gamma \alpha \mu_{\mathrm{t}} \mathrm{G}(\eta)$ under credit rationing. Thus

$$
\mathrm{k}_{\mathrm{t}+1}=[\hat{\mathrm{z}}-(\gamma / \mathrm{q}) \mathrm{G}(\eta)]\left[\mathrm{w}\left(\mathrm{k}_{\mathrm{t}}\right)-\mathrm{m}_{\mathrm{t}}\right] \equiv \phi\left[\mathrm{w}\left(\mathrm{k}_{\mathrm{t}}\right)-\mathrm{m}_{\mathrm{t}}\right]
$$

holds for all $t \geq 0$. In addition, by definition $\mathrm{p}_{\mathrm{t}} / \mathrm{p}_{\mathrm{t}+1} \equiv\left(\mathrm{m}_{\mathrm{t}+1} / \mathrm{m}_{\mathrm{t}}\right)\left(\mathrm{M}_{\mathrm{t}} / \mathrm{M}_{\mathrm{t}+1}\right) \equiv \mathrm{m}_{\mathrm{t}+1} / \sigma \mathrm{m}_{\mathrm{t}}$. Therefore (29) can be rewritten as

$$
\mathrm{m}_{\mathrm{t}+1} / \sigma \mathrm{m}_{\mathrm{t}}=\psi \mathrm{f}^{\prime}\left(\mathrm{k}_{\mathrm{t}+1}\right) /\left[\mathrm{q}-\mathrm{w}\left(\mathrm{k}_{\mathrm{t}}\right)\right]
$$

Equations (31) and (32) describe the evolution of equilibrium sequences $\left\{k_{t}, m_{t}\right\}$ when credit is rationed.

\section{A. Steady State Equilibria}

We now define the function $\mathrm{H}(\mathrm{k})$ by

$$
H(k) \equiv f^{\prime}(k) /[q-w(k)]
$$


Then a steady state (monetary) equilibrium satisfies the following conditions:

$$
\begin{aligned}
& \mathrm{H}(\mathrm{k})=1 / \sigma \psi \\
& \mathrm{m}=\mathrm{w}(\mathrm{k})-\mathrm{k} / \phi .
\end{aligned}
$$

It will clearly be necessary to establish some properties of the function $\mathrm{H}$. These are stated in Lemma 1.

Lemma 1 . The function $\mathrm{H}$ satisfies

(a) $\quad \lim _{k \rightarrow 0} H(k)=\infty$.

(b) $\quad \lim _{\mathrm{k} \rightarrow \hat{\mathrm{k}}} \mathrm{H}(\mathrm{k})=\infty$

where $\hat{\mathrm{k}} \equiv \mathrm{w}^{-1}(\mathrm{q})$, and

(c) $\begin{aligned} \mathrm{H}^{\prime}(\mathrm{k}) & \leq 0 ; \quad \mathrm{k} \leq \mathrm{f}^{-1}(\mathrm{q}) \\ & \geq 0 ; \quad \mathrm{k} \geq \mathrm{f}^{-1}(\mathrm{q}) .\end{aligned}$

Proof. Part (a) of Lemma 1 is, of course, immediate from the Inada conditions and $w(0)=0$. Part (b) is also obvious. For (c), straightforward differentiation yields that

$$
H^{\prime}(k)=-f^{\prime \prime}(k)[f(k)-q] /[q-w(k)]^{2}
$$

establishing the result.

Lemma 1 implies that the function $\mathrm{H}$ has the configuration depicted in Figure 3.

The following proposition is now immediate.

Proposition 2. (a) Suppose that $1 / \sigma \psi>\mathrm{H}\left[\mathrm{f}^{-1}(\mathrm{q})\right]$. Then there are exactly two values of $\mathrm{k}$, denoted by $k_{1}$ and $k_{2}$ in Figure 3 , that satisfy (34). (b) Suppose that $1 / \sigma \psi<H\left[f^{-1}(q)\right]$. Then there is no monetary equilibrium. 
Hence the existence of a monetary equilibrium requires that the rate of money growth not be too large, in the sense of Proposition 2.b. When the rate of money growth is sufficiently small, there will be exactly two steady state equilibrium capital stocks, $\mathrm{k}_{1}$ and $\mathrm{k}_{2}$.

As noted in the introduction, almost all monetary growth models deliver a unique monetary steady state. However, in the presence of the credit market friction modeled here, if any monetary steady states with credit rationing exist, there will typically be two of them.

Once we have determined the values of the steady state equilibrium capital stocks, it is straightforward to determine the steady state values of real balances. These are

$$
\begin{aligned}
& \mathrm{m}_{1}=\mathrm{w}\left(\mathrm{k}_{1}\right)-\mathrm{k}_{1} / \phi \\
& \mathrm{m}_{2}=\mathrm{w}\left(\mathrm{k}_{2}\right)-\mathrm{k}_{2} / \phi .
\end{aligned}
$$

An examination of Figure 2 will quickly indicate that $m_{1}>0$ and $m_{2}>0$ hold iff $k_{2}<k^{*}$. From Figure 3 , this clearly requires that $1 / \sigma \psi<\mathrm{H}\left(\mathrm{k}^{*}\right)$. Thus, if

$$
\mathrm{H}\left[\mathrm{f}^{-1}(\mathrm{q})\right]<1 / \sigma \psi<\mathrm{H}\left(\mathrm{k}^{*}\right)
$$

there are exactly two monetary steady states with positive levels of real balances. ${ }^{14}$ Notice that this is possible for any value of $\sigma \geq 1$ only if $\psi \mathrm{H}\left(\mathrm{k}^{*}\right)>1$, or in other words, only if the rate of return on savings in the absence of money exceeds unity. This is exactly the opposite of the condition under which there can exist a steady state with positive real balances in the Diamond (1965) or Tirole (1985) models.

Notice that, in addition to the existence of multiple monetary steady states, our economy has another interesting feature. In most monetary growth models, the introduction of positive real balances absorbs savings, reduces the steady state capital stock, and raises the steady state return on savings. Here it is also the case that the introduction of money reduces the capital stock but, when (36) holds, this has the effect of reducing the steady state return on savings. This feature of our 
model echoes a theme of the literature on financial markets and development: ${ }^{15}$ capital accumulation and rates of return on savings may be positively related.

\section{Comparative Statics}

We now examine the comparative static consequences of an increase in the rate of money growth. In many monetary growth models this has the effect of increasing the steady state capital stock; in many other models it leaves the steady state capital stock unchanged. ${ }^{16}$ Here the effect of an increase in $\sigma$ depends on which steady state obtains, as illustrated in Figure 4. In particular, an increase in the rate of money growth from $\sigma$ to $\sigma^{\prime}$ does raise the value of the capital stock in the low-capital-stock steady state equilibrium. However, when the economy is in the high-capital-stock steady state, higher rates of money growth lead to reductions in the value of the steady state capital stock, as well as the level of steady state output. This result is consistent with the array of empirical evidence that the steady state rate of inflation $(\sigma)$ is negatively correlated with real performance measures across different economies.

\section{B. Dynamics}

We now turn to an investigation of dynamical equilibria in this economy. This investigation enables us to state conditions under which the low-capital-stock steady state is a saddle, and the highcapital-stock steady state is a sink. Since our economy has only one initial condition, this implies that monetary equilibria are indeterminate. In addition, when the high-capital stock steady state is a sink, we will see that paths approaching it can easily display damped oscillation. Indeed, we will also exhibit economies that possess limit cycles, so that it will be apparent that economic volatility is a real possibility here. All of these are properties possessed by few monetary growth models. Moreover, the fact that there are multiple monetary steady states, all of which can be approached starting from the given initial capital stock, implies that development trap phenomena can easily be 
observed in economies with money and a financial market friction. This observation is discussed in more detail in Section V.

\section{A Phase Diagram}

We begin by constructing a phase diagram corresponding to the dynamical system described by equations (31) and (32). To do so, we substitute (31) into (32) to obtain

$$
\mathrm{m}_{\mathrm{t}+1}=\sigma \psi \mathrm{m}_{\mathrm{t}} \mathrm{f}^{\prime}\left\{\phi\left[\mathrm{w}\left(\mathrm{k}_{\mathrm{t}}\right)-\mathrm{m}_{\mathrm{t}}\right]\right\} /\left[\mathrm{q}-\mathrm{w}\left(\mathrm{k}_{\mathrm{t}}\right)\right]
$$

We henceforth work with equations (31) and (37).

$$
\text { Equation (31) implies that } k_{t+1} \geq k_{t} \text { holds iff }
$$

$$
w\left(k_{t}\right)-k_{t} / \phi \geq m_{t}
$$

(38) at equality describes a concave locus in Figure 5 along which the per capita capital stock is unchanging. $\left(k_{t}, m_{t}\right)$ combinations below (above) this locus have $k_{t+1}>(<) k_{t}$, as shown.

$$
\text { Equation (37) implies that } m_{t+1} \geq m_{t} \text { (and } m_{t}>0 \text { ) holds iff }
$$

$$
m_{t} \geq w\left(k_{t}\right)-\left(f^{\prime}\right)^{-1}\left\{\left[q-w\left(k_{t}\right)\right] / \sigma \psi\right\} / \phi
$$

Notice that the locus defined by (39) at equality lies above the locus defined by (38) at equality in Figure 5 iff

$$
\mathrm{k}_{\mathrm{t}} \geq\left(\mathrm{f}^{\prime}\right)^{-1}\left\{\left[\mathrm{q}-\mathrm{w}\left(\mathrm{k}_{\mathrm{t}}\right)\right] / \sigma \psi\right\}
$$

or equivalently, iff

$\left(40^{\prime}\right) \quad \mathrm{H}\left(\mathrm{k}_{\mathrm{t}}\right) \equiv \mathrm{f}^{\prime}\left(\mathrm{k}_{\mathrm{t}}\right) /\left[\mathrm{q}-\mathrm{w}\left(\mathrm{k}_{\mathrm{t}}\right)\right] \leq 1 / \sigma \psi$.

Thus, in particular (39) lies above (38) iff $\mathrm{k}_{\mathrm{t}} \in\left[\mathrm{k}_{1}, \mathrm{k}_{2}\right]$.

$\left(\mathrm{k}_{\mathrm{t}}, \mathrm{m}_{\mathrm{t}}\right)$ combinations along the locus defined by (39) at equality result in unchanging levels of real balances (as do such combinations with $\left.\mathrm{m}_{\mathrm{t}}=0\right)$. $\left(\mathrm{k}_{\mathrm{t}}, \mathrm{m}_{\mathrm{t}}\right)$ combinations above (below) that 
locus have $m_{t+1}>(<) m_{t}$. Thus we have the phase portrait of the dynamical system consisting of equations (31) and (37) depicted in Figure 5.

As Figure 5 suggests, and as the local analysis below confirms, the low-capital-stock steady state is a saddle. The high-capital-stock steady state can easily be a sink. In this situation, monetary equilibrium is indeterminate, and development trap phenomena are possible. Moreover, dynamical equilibrium paths approaching the high-capital stock steady state can easily display damped oscillation. In fact, as we demonstrate by example, there are parameters for which our economy can display limit cycles. We now turn to a more formal examination of these phenomena.

\section{A Local Analysis}

Suppose we linearize the dynamical system consisting of equations (31) and (37) in a neighborhood of (any) steady state equilibrium. Then we have

$$
\left(k_{t+1}-k, m_{t+1}-m\right)^{\prime}=J\left(k_{t}-k, m_{t}-m\right)^{\prime}
$$

where $\mathrm{k}$ and $\mathrm{m}$ denote the relevant steady state values for the capital stock and real balances, and where $\mathrm{J}$ is the Jacobian matrix

$$
J=\left[\begin{array}{ll}
\partial \mathrm{k}_{\mathrm{t}+1} / \partial \mathrm{k}_{\mathrm{t}} & \partial \mathrm{k}_{\mathrm{t}+1} / \partial \mathrm{m}_{\mathrm{t}} \\
\partial \mathrm{m}_{\mathrm{t}+1} / \partial \mathrm{k}_{\mathrm{t}} & \partial \mathrm{m}_{\mathrm{t}+1} / \partial \mathrm{m}_{\mathrm{t}}
\end{array}\right]
$$

with all partial derivatives evaluated at the appropriate steady state. It is straightforward to show that

$$
\begin{aligned}
& \partial \mathrm{k}_{\mathrm{t}+1} / \partial \mathrm{k}_{\mathrm{t}}=\phi \mathrm{w}^{\prime}(\mathrm{k}) \\
& \partial \mathrm{k}_{\mathrm{t}+1} / \partial \mathrm{m}_{\mathrm{t}}=-\phi \\
& \partial \mathrm{m}_{\mathrm{t}+1} / \partial \mathrm{m}_{\mathrm{t}}=1-\left[\phi \mathrm{mf}^{\prime \prime}(\mathrm{k}) / \mathrm{f}^{\prime}(\mathrm{k})\right] \\
& \partial \mathrm{m}_{\mathrm{t}+1} / \partial \mathrm{k}_{\mathrm{t}}=\left[\mathrm{mw}^{\prime}(\mathrm{k}) / \mathrm{f}^{\prime}(\mathrm{k})\right]\left\{\phi \mathrm{f}^{\prime \prime}(\mathrm{k})-1 / \sigma \psi\right\} .
\end{aligned}
$$


Let $T(k, m)$ denote the trace of $J$ as a function of the steady state capital stock and the steady state level of real balances, and let $\mathrm{D}(\mathrm{k}, \mathrm{m})$ denote its determinant. Then simple calculations yield

$$
\begin{aligned}
& \mathrm{D}(\mathrm{k}, \mathrm{m})=\phi \mathrm{w}^{\prime}(\mathrm{k})\left[1+\mathrm{m} / \sigma \psi \mathrm{f}^{\prime}(\mathrm{k})\right]>0 \\
& \mathrm{~T}(\mathrm{k}, \mathrm{m})=1+\mathrm{D}(\mathrm{k}, \mathrm{m})\left\{\left[1+\mathrm{m} / \mathrm{kf}^{\prime}(\mathrm{k})\right] /[1+\mathrm{m} /(\mathrm{q}-\mathrm{w}(\mathrm{k}))]\right\}>0
\end{aligned}
$$

We now state

Lemma 2. $\mathrm{T}(\mathrm{k}, \mathrm{m})<(>) 1+\mathrm{D}(\mathrm{k}, \mathrm{m})$ iff $\mathrm{f}(\mathrm{k})>(<) \mathrm{q}$.

Proof. From (47), $\mathrm{T}(\mathrm{k}, \mathrm{m})<(>) 1+\mathrm{D}(\mathrm{k}, \mathrm{m})$ holds iff

$$
m / k f^{\prime}(k)<(>) m /[q-w(k)]
$$

(48) is equivalent to $q<(>) f(k)$.

It is well-known that when $\mathrm{T}(\mathrm{k}, \mathrm{m})>1+\mathrm{D}(\mathrm{k}, \mathrm{m})$ holds, the relevant steady state is a saddle. ${ }^{17}$ Since $f\left(k_{1}\right)<q$ (see Figure 3), the low-capital-stock steady state is necessarily a saddle.

Moreover, since $f\left(k_{2}\right)>q$ (see Figure 3), $T\left(k_{2}, m_{2}\right)<1+D\left(k_{2}, m_{2}\right)$ holds. Therefore, if $\mathrm{D}\left(\mathrm{k}_{2}, \mathrm{~m}_{2}\right)<1$ is satisfied, the high-capital-stock steady state is a sink. ${ }^{18}$ We now state conditions under which this occurs.

Recall that $\mathrm{m}_{2}=\mathrm{w}\left(\mathrm{k}_{2}\right)-\left(\mathrm{k}_{2} / \phi\right)$ and that $\mathrm{H}\left(\mathrm{k}_{2}\right) \equiv \mathrm{f}^{\prime}\left(\mathrm{k}_{2}\right) /\left[\mathrm{q}-\mathrm{w}\left(\mathrm{k}_{2}\right)\right]=1 / \sigma \psi$. Therefore we can write

$$
\begin{aligned}
\mathrm{D}\left(\mathrm{k}_{2}, \mathrm{~m}_{2}\right) & =\phi \mathrm{w}^{\prime}\left(\mathrm{k}_{2}\right)\left\{1+\left[\mathrm{w}\left(\mathrm{k}_{2}\right)-\left(\mathrm{k}_{2} / \phi\right)\right] /\left[\mathrm{q}-\mathrm{w}\left(\mathrm{k}_{2}\right)\right]\right\} \\
& =\phi \mathrm{w}^{\prime}\left(\mathrm{k}_{2}\right)\left\{\left[\mathrm{q}-\left(\mathrm{k}_{2} / \phi\right)\right] /\left[\mathrm{q}-\mathrm{w}\left(\mathrm{k}_{2}\right)\right]\right\} \equiv \tilde{\mathrm{D}}\left(\mathrm{k}_{2}\right) .
\end{aligned}
$$

Now $\tilde{\mathrm{D}}\left(\mathrm{k}_{2}\right)$ is a continuous function of $\mathrm{k}_{2}$, and since $\mathrm{k}^{*}=\phi \mathrm{w}\left(\mathrm{k}^{*}\right), \tilde{\mathrm{D}}\left(\mathrm{k}^{*}\right)=\phi \mathrm{w}^{\prime}\left(\mathrm{k}^{*}\right)<1$ (see Figure 2). Thus $\tilde{D}\left(k_{2}\right)<1$ holds whenever $k_{2}$ is sufficiently close to $k^{*}$. $k_{2}$ will, of course, be 
close to $\mathrm{k}^{*}$ whenever $1 / \sigma \psi$ is sufficiently close to (and below) $\mathrm{H}\left(\mathrm{k}^{*}\right)$. Thus for $\sigma$ sufficiently small, the high-capital-stock steady state will be a sink.

This observation has the following implication. Our economy has only a single initial condition; $\mathrm{k}_{0}$ is given. If $\mathrm{k}_{0}$ lies in an appropriate neighborhood of $\mathrm{k}_{2}$, then we can choose any value for $\mathrm{m}_{0}$ in a neighborhood of $\mathrm{m}_{2}$, and the economy will approach the high-capital-stock steady state. Thus monetary equilibria are indeterminate here.

\section{Examples}

In this section we consider a sequence of examples in which $f(k)=2 k^{0.5}, q=2, g(z)=1 / \bar{z}$ with $\overline{\mathbf{z}}=5.73, \gamma=8.63$, and $\alpha>0.9$ hold. For these parameter values, $\phi=1.8$ and $\psi=0.35$. Then the unique (nontrivial) nonmonetary steady state capital stock is $\mathrm{k}^{*}=3.24$, and it is easy to verify that (27) and (28) are satisfied.

Example 2. Suppose that $\sigma=1.031$. Then the low-capital-stock steady state has $\mathrm{k}_{1}=$ 0.04021 and $\mathrm{m}_{1}=0.17819$. The high-capital-stock steady state has $\mathrm{k}_{2}=3.23809$ and $\mathrm{m}_{2}=$ 0.00053. In addition, $\mathrm{D}\left(\mathrm{k}_{2}, \mathrm{~m}_{2}\right)=0.50147$, and $\mathrm{T}\left(\mathrm{k}_{2}, \mathrm{~m}_{2}\right)=1.50029<1+\mathrm{D}\left(\mathrm{k}_{2}, \mathrm{~m}_{2}\right)$ holds. Thus the high-capital-stock steady state is a sink. Moreover, since $T\left(k_{2}, m_{2}\right)>2 \sqrt{ }\left(k_{2}, m_{2}\right)$, paths approaching this steady state display locally monotone dynamics.

Example 3. If $\sigma=1.95$, then the low-capital-stock steady state has $\mathrm{k}_{1}=0.19056$ and $\mathrm{m}_{1}=$ 0.33066. The high-capital-stock steady state has $k_{2}=2.44444$ and $m_{2}=0.20545$. Furthermore, $\mathrm{D}\left(\mathrm{k}_{2}, \mathrm{~m}_{2}\right)=0.84656>\mathrm{T}\left(\mathrm{k}_{2}, \mathrm{~m}_{2}\right)^{2} / 4=0.68168$ holds. This implies that not only is the high-capitalstock steady state a sink, but that paths approaching this steady state display endogenous oscillation as they do so. 
Figure 6 displays the time path for the capital stock in this example if $k_{0}=2.4444$ (that is, if the initial capital stock equals the steady state capital stock) and if $\mathrm{m}_{0}=.05$. Evidently the capital stock undergoes large fluctuations, initially rising by more than 15 percent and then falling by more than 25 percent, en route to the steady state. Thus large initial fluctuations can be observed here, even though in the long run there is no adjustment required in the capital stock.

Example 4. Now let $\sigma=2.84714$. Here the low-capital-stock steady state has $\mathrm{k}_{1}=0.88518$ and $\mathrm{m}_{1}=0.44907$. The high-capital-stock steady state has $\mathrm{k}_{2}=1.12182$ and $\mathrm{m}_{2}=0.43593$. In addition, $\mathrm{D}\left(\mathrm{k}_{2}, \mathrm{~m}_{2}\right)=1.24344>\mathrm{T}\left(\mathrm{k}_{2}, \mathrm{~m}_{2}\right)^{2} / 4=1.20941$ holds. Thus the high-capital-stock steady state has become a source.

At least for this set of examples, low rates of money growth lead to an indeterminate steady state (with reference to the high-capital-stock steady state), but locally monotone dynamics. As the money growth rate rises, eventually endogenous economic volatility will emerge. For even higher values of the money growth rate the high-capital-stock steady state becomes a source, and the economy is forced to asymptotically approach the low-capital-stock steady state. And of course for excessively high rates of money growth, there will be no monetary steady state equilibria at all.

As the money growth rate rises between Examples 3 and 4, it is apparent that $\mathrm{J}$ has eigenvalues whose modulus passes through unity. This suggests the possibility that limit cycles can be observed. That possibility is confirmed by the following example.

Example 5. Let $\sigma=2.47$. Then the economy has a limit cycle, which is depicted in Figure 7. For this value of the money growth rate, the high-capital-stock steady state is a sink, and there is an unstable limit cycle whose orbit is displayed in the figure. Thus endogenous volatility which does not dampen over time is also a real possibility in this kind of economy. 


\section{Development Traps}

When the high-capital-stock steady state is a sink, our economy displays the following kind of development trap phenomenon. Two economies with similar, or even identical, initial capital stocks can approach different steady state equilibria, even if money retains value in both economies. In particular, one economy can follow the saddle path approaching the low-capital-stock steady state, while the other can follow one of the many paths approaching the high-capital-stock steady state. This can occur for the following reason. The economy approaching the low-capital-stock steady state must have a higher level of initial real balances than the economy approaching the high-capital-stock steady state. As a result, the former economy has a lower first period capital stock then the latter economy, a lower first period wage rate, and a correspondingly lower ability to finance investment projects internally. Since more internal finance mitigates the costly state verification problem, the economy with high initial real balances will have a more severe financial market friction. This dooms that economy to having a permanently low capital stock. In this sense economies with high capital stocks have more efficiently functioning financial markets than economies with low capital stocks.

In economies like that of example 5, of course, another type of "non-convergence" phenomenon can be observed. In particular, two economies that are identical in all respects, including their initial capital stocks, can differ with respect to their endogenous levels of initial real balances. Since $\mathrm{m}_{\mathrm{o}}$ can be chosen so that one economy approaches the high-capital-stock steady state while the other lies on the closed orbit in figure 7 , it is possible that one economy has a capital stock that converges to $k_{2}$, while the other has a capital stock that fluctuates permanently. Thus two intrinsically similar economies can experience very different long-run behavior either though neither one is permanently poorer than the other. 


\section{Conclusions}

We have examined the behavior of an economy that-in the absence of any credit market frictions-is a standard monetary growth model. The presence of an explicit credit market characterized by a simple costly state verification problem, however, substantially alters the properties of equilibria in this economy. First, if any monetary steady states exist there (generically) are two of them, and it can transpire that one is a sink and one is a saddle. Thus development trap phenomena and an indeterminacy of monetary equilibrium can be observed. In addition, economies with high (low) steady state capital stocks have relatively efficient (inefficient) financial systems. Finally, it is possible that capital stocks and the real return on savings are positively related, which here implies that higher steady state rates of inflation can be detrimental to capital accumulation, and in addition financial market frictions can be a source of endogenous economic volatility.

There are, of course, a variety of additional issues that could be addressed in this framework. One natural one would be an extension of the analysis to an open economy context. In other work (Boyd-Smith 1993b) we have used the ingredients of Sections I-III to consider the behavior of two identical (except for their initial capital stocks) economies that borrow and lend with each other, and that have no outside assets. As shown there, international borrowing and lending is a source of multiple nonmonetary steady states, and the costly state verification problem precludes the convergence of output levels in the two economies. How these results would be affected by the addition of (country specific) outside assets, with the money stocks of the two countries potentially growing at different rates, would be an interesting topic for further analysis.

There are, of course, a variety of other possible extensions of this work. One would be the introduction of additional credit market frictions. Some ingredients for an analysis of this type appear in Boyd and Smith (1992a, 1993c). Another would be the analysis of a richer set of government interventions in financial markets, both with respect to regulation of these markets, and 
with respect to government credit programs. Such interventions are widespread in virtually all economies, and would constitute a particularly fruitful area for further research. 


\section{Footnotes}

${ }^{1}$ Examples of models fitting this description are the money and growth models of Diamond (1965) and Tirole (1985); Mundell (1965); Tobin (1965); Sidrauski (1967a,b); Phelps and Shell (1969); Shell, Sidrauski, and Stiglitz (1969); and Brock (1974, 1975). Stockman (1981) produces a model where investment is subject to a cash-in-advance constraint, which delivers the property that the steady state capital stock is a decreasing function of the steady state inflation rate. Azariadis and Smith (1993) produce a model of adverse selection in credit markets with the same feature. In addition, in their model there is a unique monetary steady state that may be a sink, and paths approaching the steady state can do so nonmonotonically.

Cash-in-advance models with variable labor supply (see Cooley and Hansen 1989 for an example) have the property that higher steady state inflation reduces steady state employment and the capital stock, while leaving the capital-labor ratio unaffected. As a result, inflation is not detrimental to productivity, which is a counterfactual result (Wynne 1993). We do not consider the possibility of variable labor supply here.

${ }^{2}$ See, for instance, Mints (1945) or Friedman (1960, chapter 1).

${ }^{3}$ See Keynes (1936), Mints (1945), and Friedman (1960).

${ }^{4}$ For instance, Fischer (1991), Levine and Renelt (1992), and Wynne (1993).

${ }^{5}$ See, for example, McKinnon (1973) and Shaw (1973).

${ }^{6}$ That is, if $\mathrm{f}(\mathrm{k}) \equiv \mathrm{F}(\mathrm{k}, 1)$.

${ }^{7}$ That is, in verifying the project return, $\gamma$ units of capital are used up. The assumption that capital is consumed in the verification process follows Bernanke and Gertler (1989).

${ }^{8}$ Notice that we abstract from stochastic state verification. While this is a real restriction, Boyd and Smith (1993a) show that the welfare gains from stochastic monitoring are trivial when realistic parameter values are assumed. 
${ }^{9}$ Intermediation in this context is discussed by Williamson (1986). See Krasa and Villamil (1992) for a consideration of intermediaries that cannot perfectly diversify risk.

${ }^{10}$ See Gale and Hellwig (1985) or Williamson $(1986,1987)$.

${ }^{11}$ The assumption that credit rationing obtains is maintained because it results in a substantial technical simplification. However, credit rationing is clearly a widespread phenomenon in developing countries (McKinnon 1973), and there is substantial evidence of significant rationing of credit even in the United States (Japelli 1990). Therefore this does not seem to be an empirically unreasonable assumption.

${ }^{12} \mathrm{We}$ assume, of course, that $\phi>0$.

${ }^{13}$ Note that if $k_{t} \leq k^{*}$ and $m_{t} \geq 0$ holds, then (a.5) continues to imply that $\mu_{\mathrm{t}}<1$.

${ }^{14}$ In order to produce two steady state equilibria with positive levels of real balances, it is clearly necessary that $f\left(k^{*}\right)>q$. It is easy to produce examples satisfying this condition. For instance, example 1 does so.

When $\mathrm{f}\left(\mathrm{k}^{*}\right)>\mathrm{q}$ and $\mathrm{H}\left(\mathrm{k}^{*}\right)>1 / \sigma \psi>\mathrm{H}\left[\mathrm{f}^{-1}(\mathrm{q})\right]$ hold, then $\mathrm{k}^{*}>\mathrm{k}_{2}$. Thus if (27) and (28) hold, $\alpha \mathrm{q}>\mathrm{w}\left(\mathrm{k}_{2}\right)$ and $\phi\left[\mathrm{q}-\mathrm{w}\left(\mathrm{k}_{2}\right)\right] \geq \psi$ hold as well. Therefore credit is rationed, and potential borrowers would rather borrow than lend in each monetary steady state.

${ }^{15}$ See, for example, McKinnon (1973) and Shaw (1973).

${ }^{16}$ Models in the former category include Diamond (1965), Tirole (1985), Mundell (1965), Tobin (1965), Sidrauski (1967b), Shell, Sidrauski, and Stiglitz (1969), and Phelps and Shell (1969). Models in the second category include Sidrauski (1967a) and Brock $(1974,1975)$.

${ }^{17}$ See, for instance, Azariadis (1993, chapter 6.4).

${ }^{18}$ Again, see Azariadis (1993, chapter 6.4). 
References

Azariadis, Costas. 1993. Intertemporal macroeconomics. Oxford: Blackwell.

Azariadis, Costas, and Smith, Bruce D. 1993. Private information, money, and growth: Indeterminacy, fluctuations, and the Mundell-Tobin effect. Manuscript. Cornell University. Bernanke, Ben S., and Gertler, Mark. 1989. Agency costs, net worth, and business fluctuations. American Economic Review 79, 14-31.

Boyd, John H., and Smith, Bruce D. 1992. Intermediation and the equilibrium allocation of investment capital: Implications for economic development. Journal of Monetary Economics $30,409-32$.

- 1993a. The equilibrium allocation of investment capital in the presence of adverse selection and costly state verification. Economic Theory 3, 427-51.

- 1993b. How good are standard debt contracts?: Stochastic versus nonstochastic monitoring in a costly state verification environment. Mimeo.

- 1993c. Capital market imperfections, international credit markets, and nonconvergence. Manuscript. Federal Reserve Bank of Minneapolis.

Brock, W. 1974. Money and growth: The case of long-run perfect foresight. International Economic Review 15, 750-77.

- 1975. A simple perfect foresight monetary model. Journal of Monetary Economics $1,133-50$.

Cooley, Thomas F., and Hansen, Gary D. 1989. The inflation tax in a real business cycle model. American Economic Review 79, 733-48.

de Gregorio, J. 1992. The effects of inflation on economic growth: Lessons from Latin America. European Economic Review 36, 417-25. 
Diamond, Peter A. 1965. National debt in a neoclassical growth model. American Economic Review 55, 1126-50.

Fischer, S. 1991. Growth, macroeconomics and development. NBER Working Paper 3702.

Friedman, Milton. 1960. A program for monetary stability. New York: Fordham University Press.

Gale, Douglas, and Hellwig, Martin. 1985. Incentive-compatible debt contracts: The one-period problem. Review of Economic Studies 52, 647-63.

Japelli, Tullio. 1990. Who is credit constrained in the U.S. economy? Quarterly Journal of Economics 105, 219-34.

Keynes, John Maynard. 1936. The general theory of employment, interest, and prices. New York: Harcourt, Brace and World (1964 edition).

Krasa, Stefan, and Villamil, Anne P. 1992. Monitoring the monitor: An incentive structure for a financial intermediary. Journal of Economic Theory 57, 197-221.

Levine, R., and Renelt, R. 1992. A sensitivity analysis of cross-country growth regressions. American Economic Review 82, 942-63.

Mints, Lloyd W. 1945. A history of banking theory in Great Britain and the United States. Chicago: University of Chicago Press.

McKinnon, Ronald I. 1973. Money and capital in economic development. Brookings Institute, Washington, DC.

Mundell, R. 1965. Growth, stability and inflationary finance. Journal of Political Economy 73, 97-109.

Phelps, Edmund S., and Shell, Karl. 1969. Public debt, taxation, and capital intensiveness. Journal of Economic Theory 1, 330-46. 
Schreft, Stacey L., and Smith, Bruce D. 1994a. Money, banking, and capital formation. Manuscript. Cornell University.

. 1994b. The effects of open market operations in a model of intermediation and growth. Manuscript. Federal Reserve Bank of Richmond.

Shaw, E. 1973. Financial deepening in economic development. New York: Oxford University Press.

Shell, Karl; Sidrauski, M., and Stiglitz, J. E. 1969. Capital gains, income and saving. Review of Economic Studies 36, 15-26.

Sidrauski, Miguel. 1967a. Rational choice and patterns of economic growth in a monetary economy. American Economic Review 57, 535-45.

. 1967b. Inflation and economic growth. Journal of Political Economy 57, 796-810.

Stockman, A. 1981. Anticipated inflation and the capital stock in a cash-in-advance economy. Journal of Monetary Economics 8, 387-93.

Tirole, J. 1985. Asset bubbles and overlapping generations. Econometrica 53, 1499-528.

Tobin, J. 1965. Money and economic growth. Econometrica 33, 671-84.

Townsend, Robert M. 1979. Optimal contracts and competitive markets with costly state verification. Journal of Economic Theory 21, 265-93.

Williamson, Stephen D. 1986. Costly monitoring, financial intermediation, and equilibrium credit rationing. Journal of Monetary Economics 18, 159-79.

. 1987. Costly monitoring, loan contracts, and equilibrium credit rationing. Quarterly Journal of Economics 102, 135-45.

Wynne, M. 1993. Price stability and economic growth. The Southwest Economy, Federal Reserve Bank of Dallas. 
Figure 1.

THE EXPECTED RETURN FUNCTION

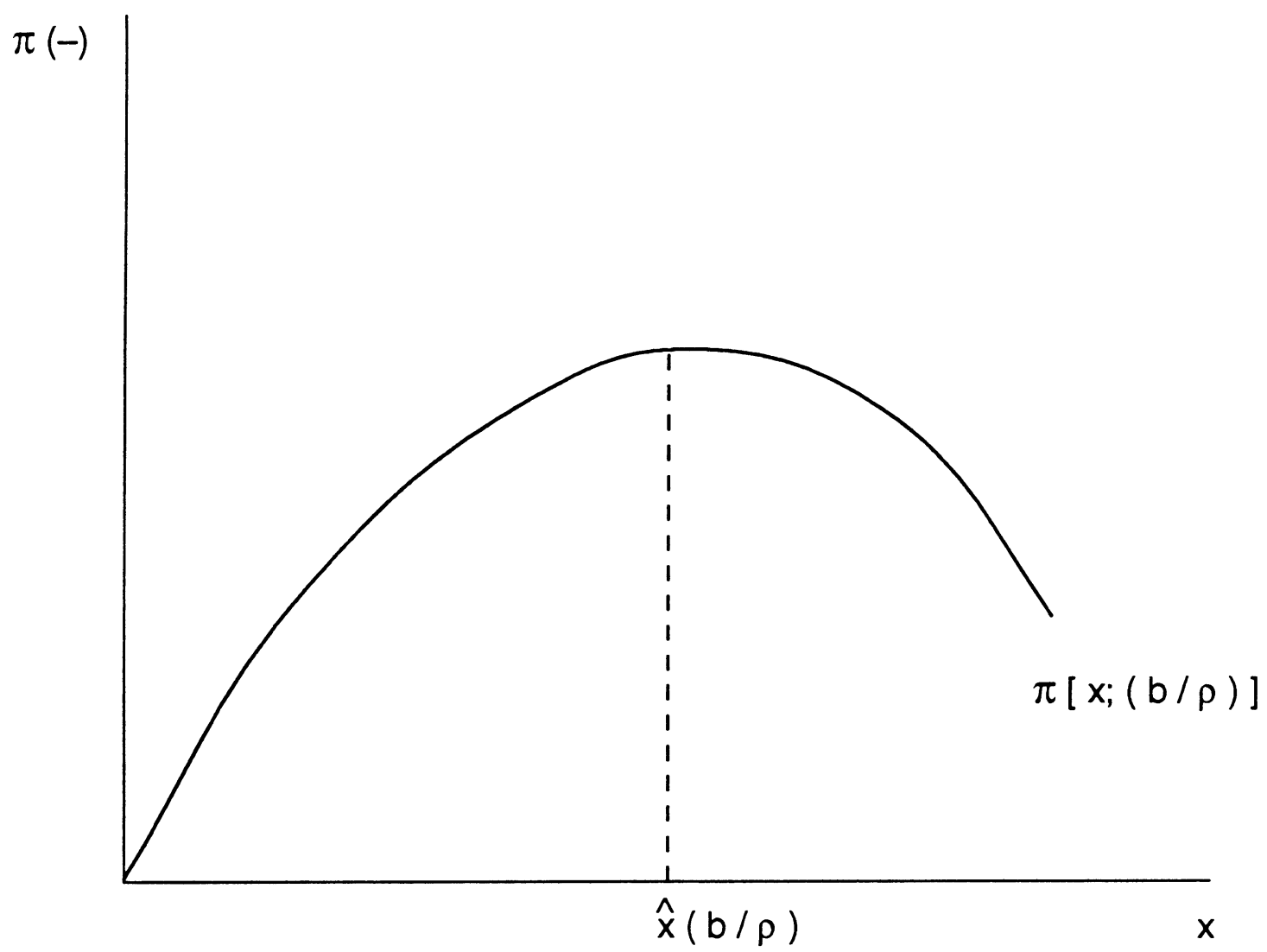


Figure 2.

THE NONMONETARY ECONOMY

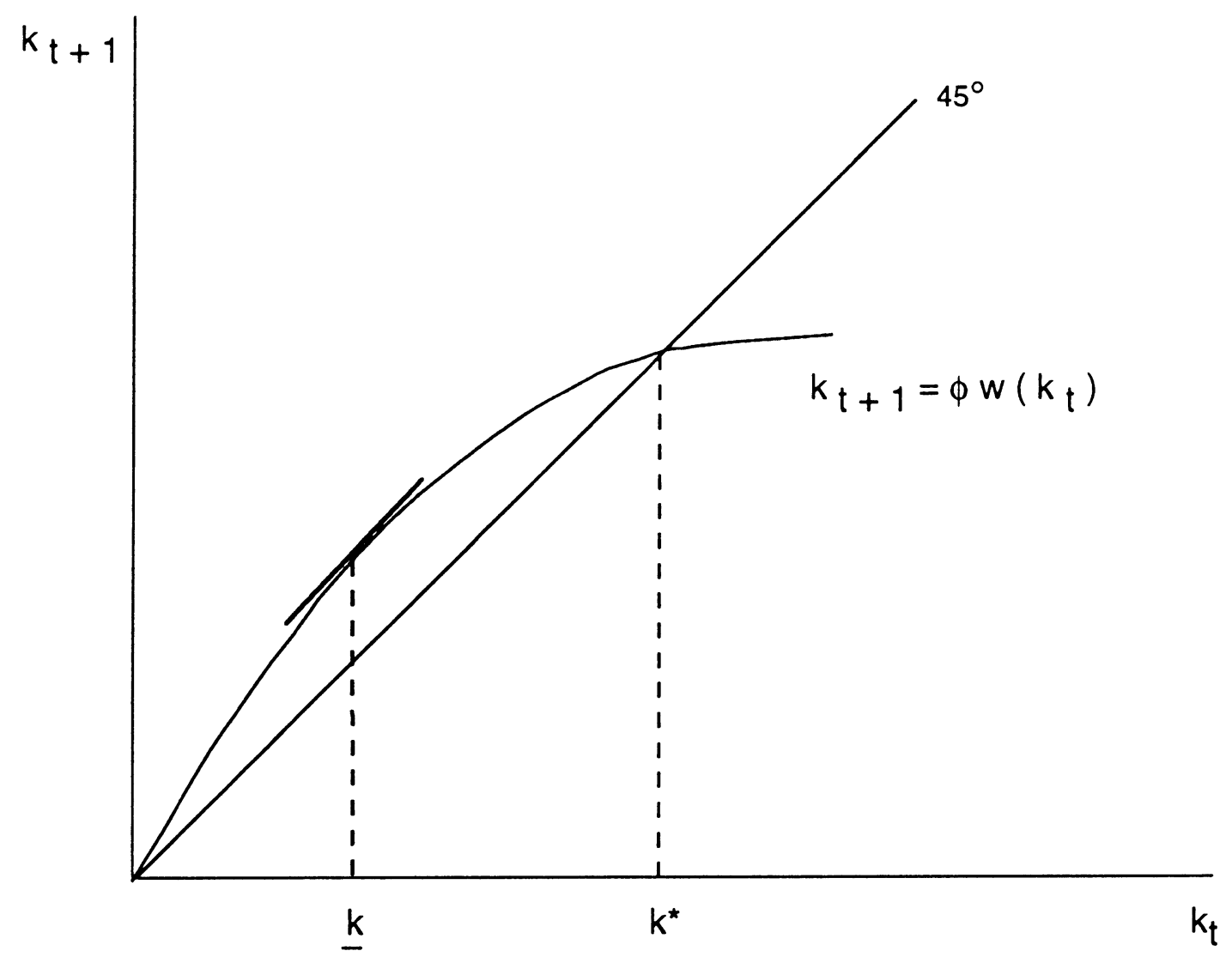


Figure 3

\section{MONETARY STEADY STATES}

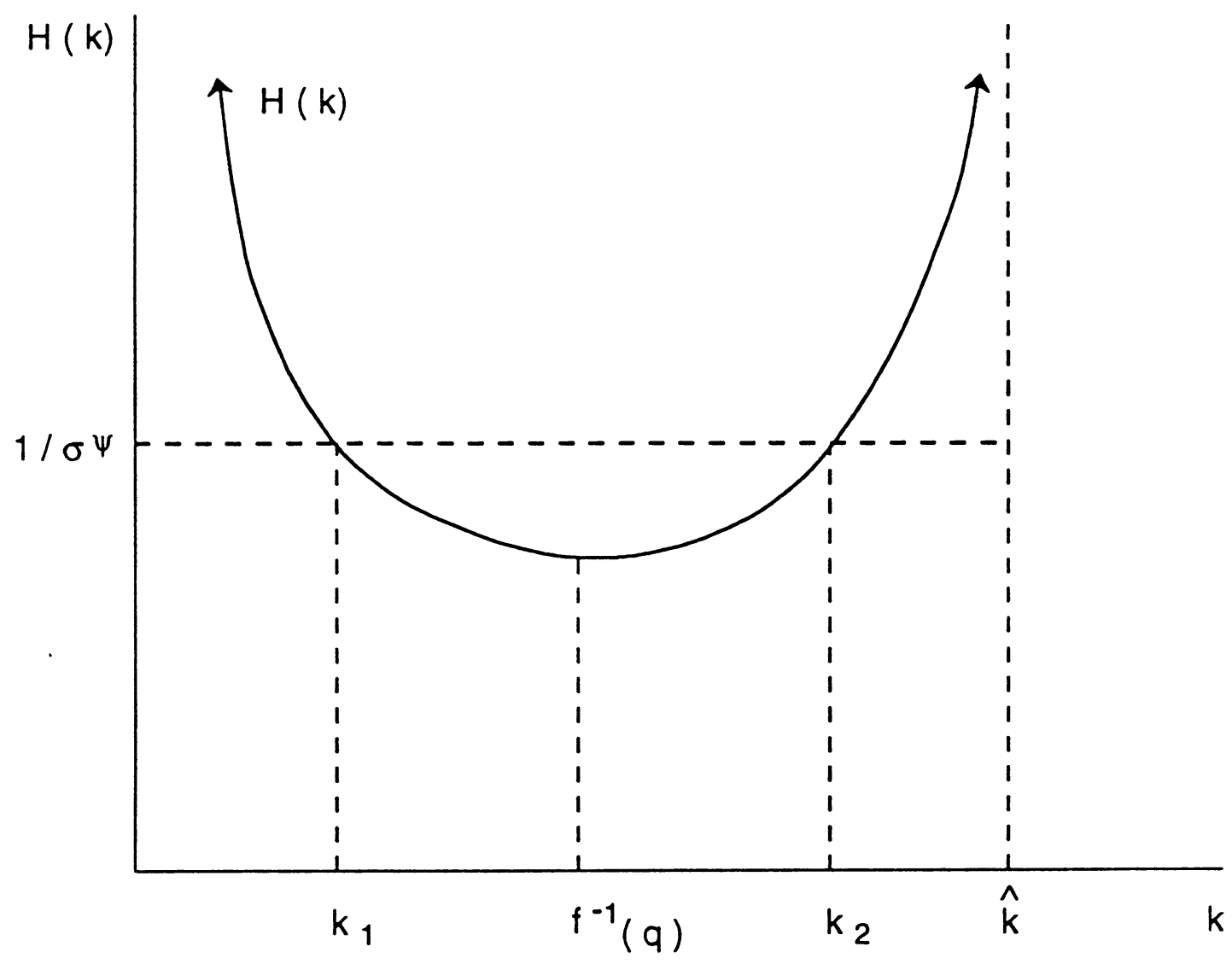


Figure 4

THE EFFECT OF AN INCREASE

IN THE RATE OF MONEY GROWTH

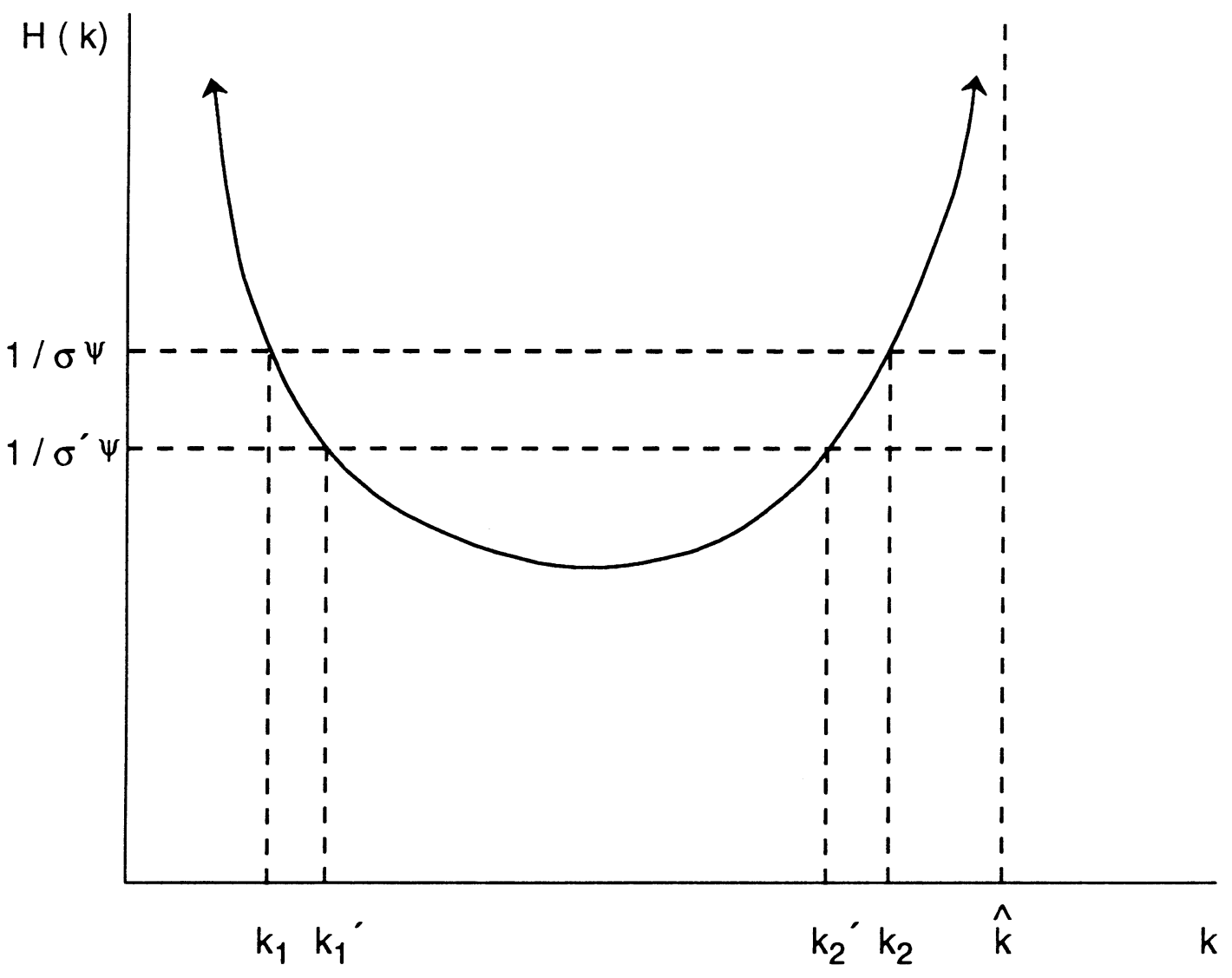


Figure 5.

PHASE DIAGRAM

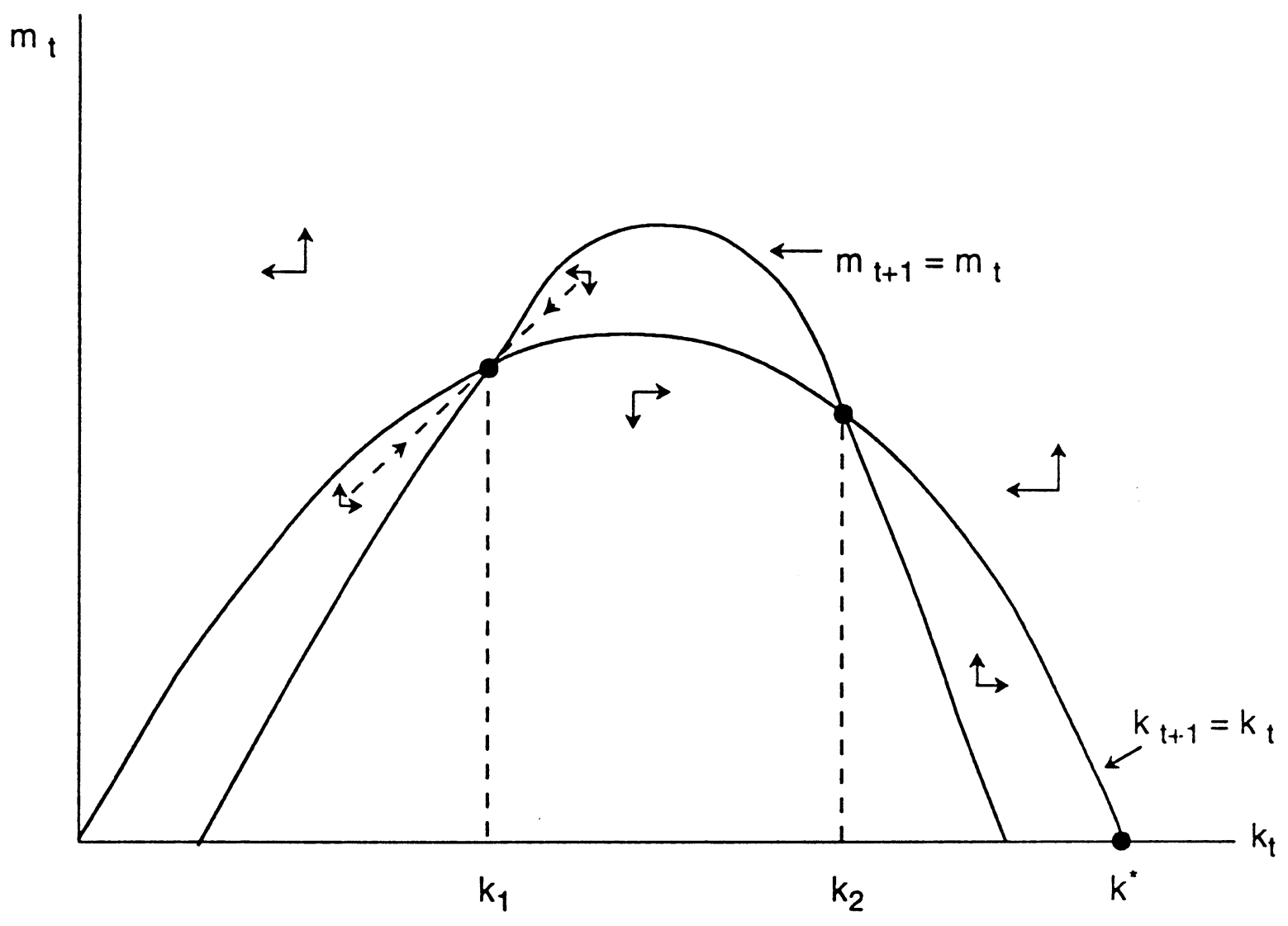


Figure 6

Example 3., $\mathrm{k}$ versus time $\mathrm{t}^{\star}$

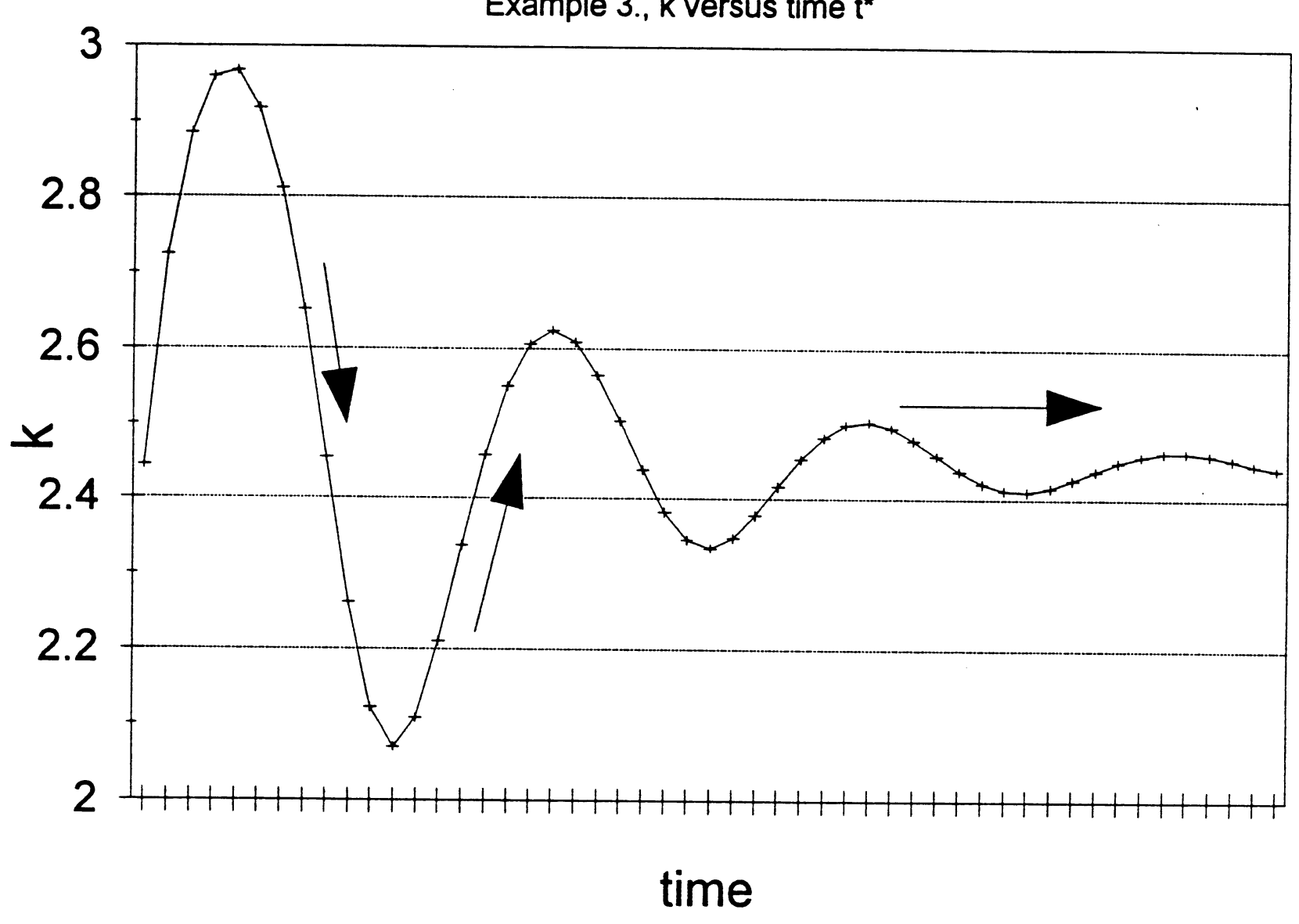

* Initial Conditions, $\mathrm{k}(0)=2.444, \mathrm{~m}(0)=.05$

Parameters: $A=2.0$, beta $=0.5, q=2.0$, phi $=1.8, p s i=0.35$, sigma $=1.95$ 


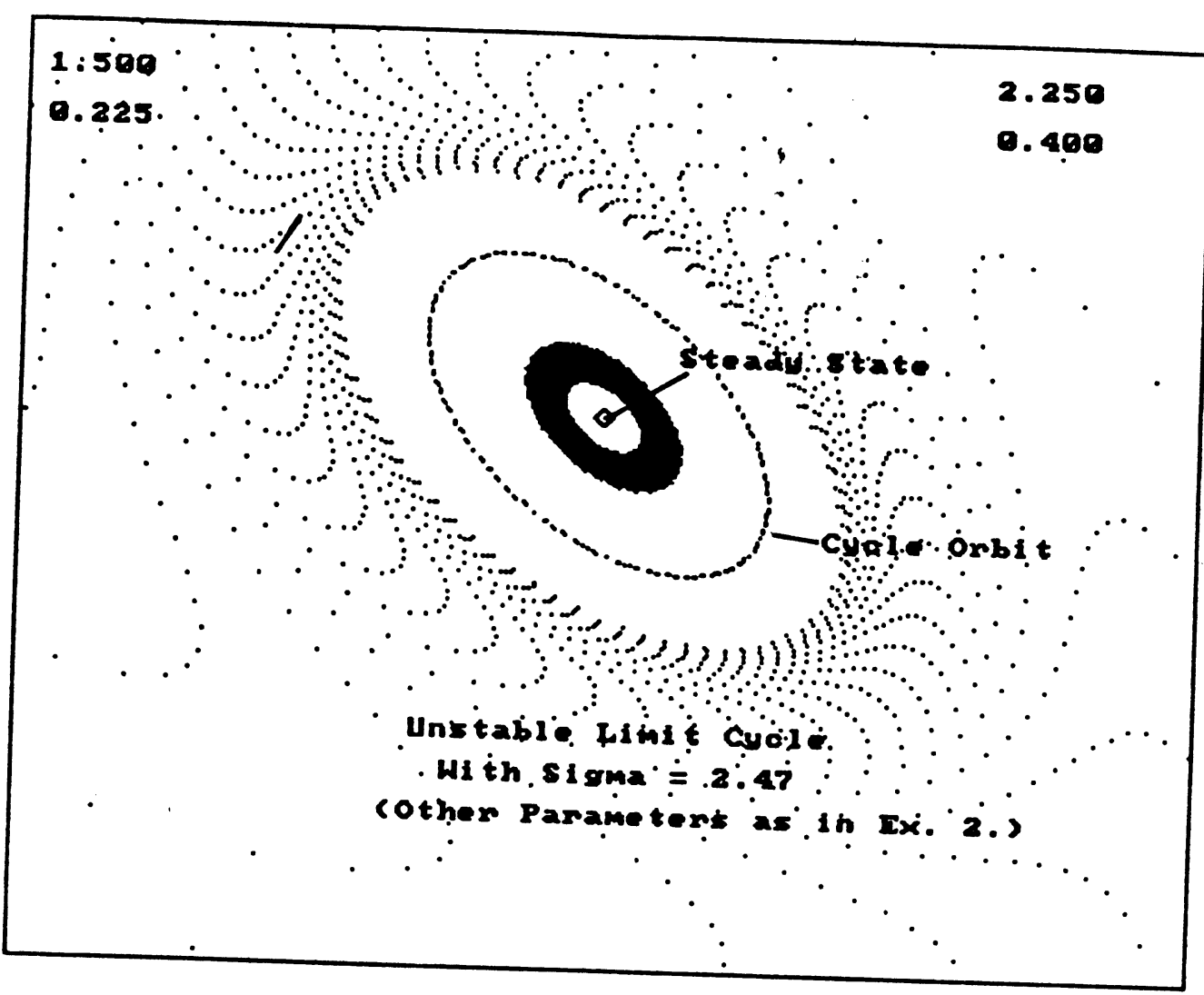


